\title{
PENDIDIKAN POLITIK VERSUS PARTISIPASI POLITIK DIERA INDUSTRI 4.0
}

\section{Dalintang Ketut Dwi Saputri ${ }^{1}$, Rika Puspita Saputri ${ }^{2}$, Anita Trisiana ${ }^{3}$}

1) Mahasiswa PPKn Universitas Slamet Riyadi Surakarta

${ }^{2)}$ Dosen PPKn Universitas Slamet Riyadi Surakarta

\begin{tabular}{l}
\hline Info Artikel \\
\hline Masuk: 24/01/ 2022 \\
Revisi: 25/01/2022 \\
Diterima: 27/01/2022 \\
Terbit: 30/01/2022 \\
Keywords: \\
political \\
education,political \\
participation,industry 4.0 \\
\hline P-ISSN: 2550-0171 \\
E-ISSN: 2580-5819 \\
DOI : 10.33061 \\
PartisipasiPolitik, \\
industri 4.0 \\
\end{tabular}

Abstract

The industrial revolution has changed the way work will be automatically through innovations. The industries participate actively as the identity organization with vision to win profit. Revolusi, based on industry walking with political system education where in paradikma there are major changes in the political system education and potential be increased. In political education can be made people understand political 4.0 in the industrial era, the progress we can see in country it makes society, more active will the development of very streaked with technology that sophisticated and society must be careful will political progress diera industrial because it will lead to a in want if not in use it well.

\section{Abstrak}

Revolusi industri telah mengubah cara kerja manusia menjadi otomatis melalui inovasi-inovasi. Para pelaku industri berperan secara aktif sebagai identitas organisasi yang memiliki visi dalam meraih keuntungan.Revolusi, industry berjalan dengan dilandasi pendidikan politik dimana dalam paradikma ini terdapat perubahan besar dalam struktur politik dengan system pendidikan dan peningkatan potensi bersikap. Didalam Pendidikan Politik ini dapat membuat masyarakat memahami Politik diera Industri 4.0, kemajuan yang dapat kita lihat di dalam Negara Indonesia ini membuat massyarakat lebih aktif akan perkembangan yang sangat melesat dengan teknologi yang canggih dan Mayarakat harus 
berhati-hati akan kemajuan politik diera indutri ini karena akan mengakibatkan hal yang tidak di inginkan jika tidak di gunakan dengan baik.

\section{PENDAHULUAN}

Pendidikan politik adalah proses pembelajaran dan pemahaman tentang hak, kewajiban dan tanggungjawab setiap warga Negara dalam kehidupan berbangsa dan bernegara. Jika dikaitkan dengan partai politik, pendidikan politik bisa diartikan sebGi usaha sadar dan tersistematis dalam mentransformasikan segala sesuatu yang berkenan dengan perjuangan partai politik tersebut kepada masanya agar mereka sadarkan peran dan fungsi. Partisipasi politik dalam sebuah Negara demokrasi merupakan sesuatu yang substansial. Salah satu alasan yang mendasar terkait hal tersebut adalah karena salah satu indicator kualitas demokrasi ditentukan oleh tinggi dan rendah serta bagaimana partisipasi politik tersebut dilakukan.Partisipasi politik adalah kegiatan seseorang atau kelompok orang untuk ikut serta secara aktif dalam kehidupan politik, antara lain dengan jalan memilih pimpinan Negara dan secara langsung atau tidak langsung memengaruhi kebijakan pemerintah.

Industri 4.0 adalah industri yang menggabungkan teknologi otomatisasi dengan teknologi cyber.Ini merupakan tren otomatisasi dan pertukaran data dalam teknologi manufaktur.Ini termasuk sistem cyber-fisik, Internet of Things (IoT), komputasi awan dan komputasi kognitif. Pendidikan politik di era industry 4.0 yaitu perkembangan zaman dari yang tradisional menjadi modern yang akan membuat bangsa lebih maju lagi, membuat Negara tidak kalah saing dengan Negara lainnya. Dapat kita ketahui bahwa kemajuan tersebut sudah terlihat di Indonesia yaitu sarana di dalam pemerintahan sampai kepedesaan yang membuat warga lebih mudah untuk melakukan segala hal.

\section{METODE}

Penelitian ini menggunakan desain studi dengan metode kuantitatif. Metode penelitian sebagai prosedur penelitian yang menghasilkan diskriptif berupa katakata tertulis atau lisan dari perilaku yang diamati, Bodgan dan Taylor (Basrowi,2013;21). Penelitian kualitatif pada hakikatnya adalah mengamati orang dalam lingkungan hidupnya, berinteraksi dengan mereka, berusaha memahami bahasa dan tafsiran mereka tentang dunia sekitar, Nasution (1996:3). 


\section{PEMBAHASAN}

\section{Pendidikan Politik}

Pedidikan politik yaitu untuk meningkatkan pengetahuan rakyat agar mereka dapat berpartisipasi secara maksimal dalam system politik, Rusadi Kantaprawira (2004:55). Dengan adanya pendidikan politik ini dapat memudahkan masyarakat untuk mengetahui dan dapat berpartisipasi dalam politik, karna setiap tahun pasti ada pemilihan umum dengan pendidikan politik ini masyrakat dapat beperan serta dalam politik. Pendidikan sangat penting untuk meningkatkan pengetahuan dan disini berfokus pada politik, warga dapat memahami dan mengetahui politik, dimana pasti ada proses pemilihan yaitu dengan melalui pemilihan suara.

\section{Partisipasi Politik}

Partisipasi politik merupakan kegiatan seseorang atau kelompok orang untuk ikut serta secara aktif dalam kehidupan politik, antara lain dengan jalan memilih pimpinan Negara secara langsung atau tidak langsung mempengaruhi kebijakan pemerintah Meriam Budiardjo (2008:367). Jadi partisipasi adalah kegiatan yang dilakukan seseorang kelompok untuk berikut serta dalam kehidupan politik, contoh saja kegiatan dalam pemilihan suara, menghadiri rapat umum. Partisipasi juga merupakan kegiatan sukarela yang dilakukan warga masyarakat dengan melalui mengambil bagian dalam proses pemilihan penguasaan yang dapat dilakukan secara langsung atau tidak langsung dalam pembentukan kebijakan. Huntington dan Nelson dalam "No Easy Cholse: political participation in deleloping coutries"dikutip Budiarjo (2008:326 dimana kegiatan warga yang betindak sebagaimana pribadi yang mempengaruhi perbuatan keputusan politik.

Partisipasi politik juga merupakan kegiatan warga Negara biasa nya mempengaruhi proses pembuatan dan pelaksanaan kebijakan umum dan ikut menentukan pemimpin pemerintah, Ramlan Surbakti sebagaimana dikutib Rahmat Arifin (1998:128), dapat disimpulkan Bahwa sudah menjadi kebiasaan warga dalam kegiatan dalam ikut menentukan pilihan melalui suara untuk dapat menentukan pimimpin yang diinginkan. Kegiatan legal yang dilakukan oleh warga perorangan yang secara langsung dan juga tidak langsung untuk mempengaruhi pilihan pemimpin petinggi pemerintahan. 
Partisipasi politik dapat dilakukan secara konvensional dan juga non konvensional. Secara konvensialan disini dilakukan seperti pemberian suara sering disebut voting, dan bisa juga ikut dalam kegiatan kampaye, sedangkan non konvensional seperti demokrasi. Konvensional juga suatu bentuk partisipasi normal dalam demokrasi modern, dan non konvensional termasuk dalam beberapa yang mungkin legal contoh peisi maupun illegal, kekerasan.

\section{Industri 4.0}

Industry 4.0 adalah tranformasi komprehensif dari keseluruhan aspek produksi industry melalui penggabungan teknologi digital dan internet dengan industry konvensional. Menurut Herbert Me Closky, yang dikutip Budiarjo (2008:367) bahwa partisipasi politik adalah kegiatan sukarela dari warga masyarakat melalui mereka yang mengambil bagian dalam proses pemilihan oenguasa dan secara langsung atau tidak langsung, dalam pembentukan kebijakan umum selama selanjutnya. industry 4.0 merupakan lingkungan dimana entitasnya selalu terhubung dan mampu untuk berbagi informasi satu dengan yang lain. Selanjutnya industry 4.0 yaitu integrasi dari Cyber Physical system dan internet of Thing and Services ke dalam proses industry meliputi manufaktur dan logistic. Politik di era industri 4.0 ini akan membuat masyarakat Indonesia lebih faham akan politik di Indonesia, kemajuan tegnologi yang akan di manfaatkan oleh masyarakat yang sudah faham akan manfaat kemajuan tegnologi di Indonesia.

Masyarakat inilah yang akan membuat Negara maju dengan persaingan antar Negara yang sangatlah berat, pemerintahan yang akan mengelola bagaimana untuk menjadika kemajuan tegnologi ini menjadi suatu hal yang akan membuat Negara lebih maju lagi, jika pemerintahan tidak dapat memanfaatkan kemauan industry 4.0 ini akan mengakibatkan boomerang bagi Negara. Dapat kita lihat Indonesia belum sepenuhnya berhasil menggunakan era industri 4.0 karena masih banyak penyalahgunaan di dalam penggunaan teknologi tersebut. Contohnya kasus e ktp yang menggunakan alat yang sangat menguntungkan bagi massyarakat Indonesia tetapi hal tersebut disalahgunakan oleh orang yang tidak bertanggung jawab.

Mendorong orang untuk berpartisipasi dalam hal politik dapat dilakukan dengan sering mengikuti diskusi-diskusi politik melalui media, meningkatkan karakter setiap orang dengan keperdulian sosial biasanya biasa terlibat dalam aktifitas politik, bisa juga dengan pendidikan melalui sosialisasi.

\section{KESIMPULAN DAN SARAN}

\section{KESIMPULAN}


Pendidikan politik saat ini belum berjalan dengan baik, kenyataan masih banyak acuh tak acuh akan pemilihan, meskipun mereka ikut serta dalam partisipasi dan Cuma ikut-ikutan. Pendidikan politik ini dilakukan agar banyak yang mengerti dan memahami tentang politik, karena dalam kehidupan tidak jauh berhubungan dengan politik, dari masyarakat aja seperti pemilihan RT atau Lurah dan lain-lain. Semua menggunakan suara atau voting, dimana pendidikan politik perlu. Dan bukan saja pendidikan tetapi juga didampingi dengan partisipasi, sangat dibutuhkan partisipasi dalam politik karena tanpa partisipasi dari masyarakat juga tidak akan bisa berjalan karena masyarakat sebagian dari pada pada pelaksanaan tersebut. Dan adanya politik di era 4.0 ini membuat masyarakat lebih memahami tentang politik diindonesia.

\section{SARAN}

Untuk mewujudkan partisipasi politik secara maksimal dapat dilakukan dengan mengintensifkan palaksanaa politik dari bawah atau kampong. Pemerintah juga harus mengoptimalkan peran pendidikan sebagai mitra untuk terlaksananya pendidikan politik. Dengan penyelenggaraan pemilu dapat lebih mudah untuk memahami dan mengerti akan politik. Pemilihan juga dihatapkan dari pihak-pihak partai politik memberikan sosialisasi politik secara efektif dan melalui seminar tentang pendidikan politik.

\section{DAFTAR PUSTAKA}

Almond, Gabriel \& Sidney Verba, (1984), Budaya Politik (Tingkah Laku dan Demokrasi di Lima Negara), Bina Aksara, Jakarta

Basrowi. Memahami Penelitian Kualitatif. Jakarta: Rineka Cipta,2013

Nasution. (1996). Metode Penelitian Naturalistik Kualitatif, Bandung Tarsito

Kantaprawira Rusadi, 2004. Sistem Politik Indonesia, Suatu Model Pengantar, Edisi Revisi, Sinar baru Algensindo, Bandung

Budiarjo Miriam,2008, Dasar Dasar Ilmu Politik, Edisi Revisi, PT.Granedia Pustaka Utama,Jakarta.

Huntington Samuel \& Joan M, Nelson, 1997, No Easy Cholse : Political Participation in DevelopingCountries, Cambrige, Harvard.

Surbakti, Ramlan, Memahami Ilmu Politik, Jakarta:Gramedia Widya Pustaka Utama, 1992 
Me Closky Herbert, 1972, Political Participation, Internasional Encyclopedia of The Social Sciences ed ke 2. Mac Milan Company, New York.

Mas'oed Mochtar \& Colin Mac Andrews, 1978, Perbandingan Sistem Politik, Gajah Mada University Press, Yogyakarta. 